\title{
Q-VD-OPh, a pancaspase inhibitor, reduces trauma-induced apoptosis and improves the recovery of hind-limb function in rats after spinal cord injury
}

\author{
A. Çolak; V. Antar*; A. Karaoğlan; O. Akdemir*; E. Sahan**; Ö. Çelik*** and A. Sağmanligil* \\ Department of Neurosurgery, Maltepe University, School of Medicine, Istanbul; Department of Neurosurgery* and Pathology**, Taksim \\ Education and Research Hospital, Istanbul; Department*** of Molecular Biology and Genetics, Kültür University Faculty of Arts and Sciences, \\ Istanbul. Turkey.
}

\section{Summary}

Background. Various caspases have been implicated in the development of secondary damage after spinal cord injury (SCI). Anticaspase therapy that targets only one caspase has been investigated in a variety of in vitro and in vivo studies. This study examined the neuroprotective effects of Q-VD-OPh, a pan-caspase inhibitor, in a rat model of SCI.

Methods. Thirty Wistar albino rats were divided into 3 groups of 10 each: the sham-operated controls (group 1), the trauma-created controls (group 2), and the QVD-OPh-treated rats (group 3). An SCI (a trauma of $40 \mathrm{~g}-\mathrm{cm}$ ) was produced at the thoracic level (T8-T10) by the weight-drop technique. The response to injury and the neuroprotective effects of $Q-V D-O P h$ were investigated by histopathologic examination and terminal deoxynucleotidyl transferase dUTP nick-end labeling (TUNEL) 24 hours and 5 days after trauma. The inclined plane technique of Rivlin and Tator and a modified version of Tarlov's grading scale were used to assess the functional status of the rats 24 hours, 3 days, and 5 days after injury.

Results. Twenty-four hours after trauma, light microscopic examination of a specimen taken from group 2 rats revealed hemorrhage, necrosis, vascular thrombi, and edema. Group 3 tissue samples showed similar features at that time. Twenty-four hours after trauma, the mean apoptotic cell number was $4.47 \pm 0.35$ cells in group 2 and $1.58 \pm 0.33$ in group 3 . Five days after injury, the mean apoptotic cell count was $4.35 \pm$ 0.47 in group 2 and $1.25 \pm 0.34$ in group 3 . Thus the number of TUNEL-positive cells in an injured spinal cord was greatly reduced by treatment with Q-VDOPh. The neurologic function scores (both the inclined plane performance and motor grading scores) were significantly better in the Q-VD-OPh-treated group than in the trauma-created control group.

Conclusion. The marked antiapoptotic properties of

Recibido: 18-08-08. Aceptado: 31-05-09
Q-VD-OPh due to the inhibition of all caspases render it a promising novel agent. A therapeutic strategy using Q-VD-OPh may eventually lead to the effective treatment of SCI in humans.

KEY WORDS: Caspase. Q-VD-OPh. TUNEL. SCI. Secondary damage. Spinal cord injury.

Q-VD-OPh, un inhibidor de caspasas, reduce la apoptosis relacionada con el trauma y mejora la recuperación funcional en ratas tras lesión medular traumática

\section{Resumen}

Introducción. En el desarrollo de daño secundario tras lesión medular están implicadas diversas caspasas. La terapia anti-caspasas ha utilizado como diana una sola caspasa que ha sido investigada en una gran variedad de estudios tanto in-vitro como in-vivo. Estos estudios han examinado el efecto neuroprotector del Q-VD-PPh, un inhibidor pan-caspasa, en un modelo de lesión medular en rata.

Material y métodos. Se dividieron 30 ratas Wistar en tres grupos de 10 ratas cada uno: una lesión medular traumática (con un trauma de $40 \mathrm{~g}-\mathrm{cm}$ ) se realizó a nivel torácico grupo control (grupo 1), grupo trauma control (grupo 2) y el grupo de ratas tratadas con QVD-OPh (grupo 3) se realizó a nivel torácico (T8-T10) mediante la técnica de caída de peso. La respuesta a la lesión y los efectos neuroprotectores de Q-VD-OPh se valoraron mediante el examen histopatológico y la técnica de TUNEL 24 horas y 5 días tras el traumatismo. Se usó la prueba del plano inclinado de Rivlin y Tator y una versión modificada de la escala de Tarlov para valorar el resultado funcional de las ratas 24 horas, 3 días y 5 días tras la lesión.

Abbreviations. DMSO, dimethyl sulfoxide; SCI, spinal cord injury; TUNEL, the terminal deoxynucleotidyl transferase-mediated dUTP-biotin nick end labeling. 
Resultado. Veinticuatro horas tras la lesión, el estudio histopatológico de las secciones obtenidas del grupo 2 revelaron hemorragia, necrosis, trombos vasculares y edema. Las secciones obtenidos del grupo 3 mostraron hallazgos similares en ese momento. 24 horas tras la lesión el número de células apoptóticas fue $4.47 \pm 0.35$ en el grupo 2 y $1.58 \pm 0.33$ en el grupo 3. Cinco días tras la lesión el número medio de células apoptóticas fue de $4.35 \pm 0.47$ en el grupo 2 y de $1.25 \pm 0.34$ en el grupo 3 . De esta forma el número de células TUNEL positivas en la médula dañada se redujo de forma considerable con el tratamiento con Q-VD-OPh. La función neurológica (tanto con el plano inclinado como con las escalas motoras) fueron significativamente mejores en el grupo de ratas tratadas mediante Q-VD-OPh que en el grupo control.

Conclusión. Los marcados efectos antiapoptóticos de la Q-VD-OPh debido a la inhibición de todas las caspasas hace que sea un agente prometedor.

PALABRAS CLAVE: Caspasa. Q-VD-OPh. TUNEL. Lesión medular traumática. Lesión secundaria.

\section{Introduction}

It is well known that spinal cord injury (SCI) is caused by 2 mechanisms: primary trauma and secondary damage. Types of primary trauma include mechanical compression, bleeding, edema, electrolyte disturbance, etc, all of which can lead to irreversible tissue injury that is almost impossible to treat. Types of secondary damage include edema, hemorrhage, inflammatory reaction, ischemia, the disruption of energy metabolism, and apoptotic cell death ${ }^{13,20}$. Results from clinical and experimental studies suggest that after SCI, 2 types of cell death (necrotic and apoptotic) occur and that necrotic cell death, which occurs first, is followed by a series of deleterious events that promote progressive apoptotic cell death ${ }^{2,4,6,7,18-20}$. Caspases, which are a superfamily of cysteine proteases, have a conserved pentapeptide motif and require an aspartic acid residue to cleave cellular proteins. Research has revealed that the activation and activity of caspases are critical for the appropriate and timely execution of apoptosis, in which multiple enzymes and molecules are involved at several molecular levels ${ }^{14,24,28,29,35}$. In experimental and clinical studies, the function of caspases has been investigated to explain the pathogenesis of secondary injury after $\mathrm{SCI}^{2-4,6,7,10,13,14,17-}$ $20,30,38$. Research has shown that traumatic injury to the spinal cord activates a large number of caspases that cleave each other as well as cellular proteins at various stages of this active process ${ }^{29,32}$. Panactivation of all caspases finally causes apoptotic cell death.

During the last decade, the clinical understanding of apoptosis has advanced substantially, not only in experimental models but also in humans ${ }^{3,4,7,10,13,15,8,20,24,29,32,33}$. The discovery of apoptosis focused scientific attention on apoptosis-targeting therapeutics ${ }^{5,9,22,33,35}$. A variety of antiapoptosis-based therapeutic strategies have been used, depending on the molecular target, but therapeutic approaches that target an individual caspase are now the focus of intense biological and clinical interest ${ }^{5,8,9,22,33,35}$. Q-VD-OPh is a peptide-derived broad-spectrum caspase inhibitor that irreversibly and effectively inhibits pancaspases $^{5}$. Q-VD-OPh has major advantages (improved potency, stability, and reduced cellular toxicity) over other caspase inhibitors such as z-VAD-fmk. Researchers who assessed the activity of Q-VD-OPh in vitro and in vivo have shown that it inhibits apoptosis in various cell types and species $5,12,21,23,25,26,34,36,37,39,40$. Nonner and colleagues ${ }^{23}$ and White and colleagues ${ }^{36}$ have shown that Q-VD-OPh is very effective in increasing cell survival and in preventing apoptosis that induced different stress.

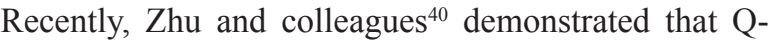
$\mathrm{VD}-\mathrm{OPh}$ reduced infarct size in a mouse model of neonatal cerebral hypoxia-ischemia. In a rat neonatal stroke model, Renolleau and colleagues ${ }^{26}$ showed that Q-VD-OPh reduced cell death and provided significant neuroprotection. In another study performed by Yang and colleagues ${ }^{37}$ on an experimental model of Parkinson's disease and Huntington's disease, Q-VD-OPh significantly reduced dopamine depletion in the striatum and the loss of dopaminergic neurons in the substantia nigra, which led to protection against those diseases. However, to our knowledge, Q-VD-OP has not been investigated in any model of SCI, and this is the first study to demonstrate the neuroprotective effect of that molecule after SCI.

\section{Materials and methods}

\section{Experimental groups}

Thirty adult male Wistar albino rats (weight, 250$350 \mathrm{~g}$ ) were used in this study. The rats were randomly divided into 3 groups of 10 rats per group. In group 1 (the sham-operated controls), laminectomy was performed and spinal cord samples were obtained. Group 2 rats (the trauma-created controls) underwent a traumatic intervention after laminectomy, treated with DMSO, and samples from the injured cord were collected. Group 3 rats (those treated with Q-VD-OPh) received an intraperitoneal dose of Q-VD-OPh $0.4 \mathrm{mg} / \mathrm{kg}$ after the traumatic intervention. The same dose was repeated at 24 hours post-injury in this group.

\section{Surgical procedures}

The surgical procedure was performed after each rat had received a general anaesthetic (an intramuscular 
injection of ketamine $60 \mathrm{mg} / \mathrm{kg}$ [Parke-Davis, Istanbul, Turkey] and xylazine $10 \mathrm{mg} / \mathrm{kg}$ [Rompun, Bayer, Istanbul, Turkey]). The dorsal region of each rat was shaved and cleaned. A 15- to 20-mm midline incision was made at the T8 to T10 level. The paravertebral muscles were dissected away to expose the T8 to T10 vertebrae. The spinal cord was exposed via a 3-level T8 to T10 laminectomy. The dura mater was left intact. In group 2 and group 3 rats, spinal cord trauma was produced by the weight-drop technique described in detail by Allen ${ }^{1}$. The intensity of the trauma was $40 \mathrm{~g}$-cm. Twenty-four hours after SCI, 5 rats from each group were killed with an intraperitoneal injection of high-dose ketamine and were transcardially perfused with $200 \mathrm{~mL}$ of saline, after which they were fixed with $200 \mathrm{~mL}$ of a $10 \%$ neutral formaldehyde solution. A $2-\mathrm{cm}$ segment of the spinal cord at the injury site was removed, embedded in paraffin, and cut transversely in $5-\mu \mathrm{m}$ serial sections. Three group sections were taken (1 from the epicenter of the injury, 1 from a site $3 \mathrm{~mm}$ rostral to the epicenter, and 1 from a site $3 \mathrm{~mm}$ caudal to the epicenter). The sections were harvested for study by means of a light microscope and terminal deoxynucleotidyl transferase dUTP nick-end labeling (TUNEL). The remaining 5 rats in the 3 groups were used in functional recovery experiments. At the end of 5 days, the 15 rats ( 5 in each group) were killed, perfused, and fixed, and spinal cord specimens were harvested for study with a light microscope and TUNEL as described above.

\section{Treatment}

The rats that underwent the sham operation received no treatment. Each animal in group 3 was treated with 0.4 $\mathrm{mg} / \mathrm{kg}$ Q-VD-OPh (Calbiochem GmbH, Med-Lab, Istanbul, Turkey) at immediately after trauma. That dose was repeated 24 hours after the injury. Group 2 rats received the same dose of DMSO as in group 3.

\section{Functional recovery experiments}

In the experiments on functional recovery, 5 rats from each group were assessed with the inclined plane technique and a modified Tarlov's grading scale as described in detail below on days 1,3 , and 5 after $\mathrm{SCI}^{27,31}$. According to Tarlov's grading scale, grade 1 represents no voluntary hind-limb movement; grade 2, minimal hind-limb movement but the inability to stand; grade 3 , the ability to stand but the inability to walk; grade 4 , the ability to walk with mild spasticity or incoordination of the hind limbs; and grade 5 , the ability to walk normally.

\section{Light microscopic examination}

For light microscopic examination, spinal cord samples were taken both 24 hours and 5 days after trauma. The samples were fixed in a $10 \%$ neutral formaldehyde solution and were embedded in paraffin. As noted above, 3 serial sections were taken ( 1 from the epicenter of the injury site, 1 from a site $3 \mathrm{~mm}$ rostral to the epicenter, and 1 from a site $3 \mathrm{~mm}$ caudal to the epicenter). Tissue sections (thickness, $5 \mu \mathrm{m})$ were cut transversely and stained with hematoxylin and eosin for light microscopic examination.

\section{TUNEL staining and detection of apoptosis}

The TUNEL method was used to assess in situ cell death ${ }^{11}$. Three serial sections were obtained as described above ( 1 from the epicenter of the injury site, 1 from a site $3 \mathrm{~mm}$ rostral to the epicenter, and 1 from a site $3 \mathrm{~mm}$ caudal to the epicenter) 24 hours and 5 days after injury. Sections $5 \mu \mathrm{m}$ thick were taken from the serial sections and were prepared for TUNEL staining. A Calbiochem colorimetric detection kit QIA33 (EMD Biosciences Inc, Darmstadt, Germany) was used to facilitate the identification of apoptotic nuclei in paraffin-embedded tissue sections by the end-labeling (FragEL) of deoxyribonucleic acid. To compare the extent of apoptosis quantitatively after $\mathrm{SCI}$ in groups 2 and 3, all apoptotic cells were counted in the TUNEL-stained sections from each group $(n=5)$. A blinded researcher who was not involved in the experiment counted all TUNEL-positive cells in 15 fields for each slide under high-power fields (original magnification $\times 40$ ) with a light microscope. These 15 fields were randomly selected from slides without discrimination between white and gray matter. Then the mean count for each set of specimens ( 24 hours and 5 days) in each group was calculated and compared.

\section{Statistical analysis}

Results of the quantitative studies were expressed as the mean $\pm \mathrm{SD}$. Statistical comparisons between the groups were performed with the Kruskal-Wallis and Mann-Whitney $\mathrm{U}$ tests. A $P$ value of $<.05$ was considered statistically significant.

\section{Results}

\section{Light microscopic examination}

Light microscopic examination of the specimens taken from group 1 rats revealed a spinal cord that was normal in appearance, as expected. Twenty-four hours after injury, the architecture of the spinal cord was distorted in group 2 rats. Hemorrhage and edema were severe in both the gray and the white matter. Other features noted on some slides were necrosis, vacuolar degeneration, and vascular thrombosis. At that time, the architecture of the spinal cord tissue obtained from group 3 rats was relatively better preserved than that in group 2 rats. In group 3, hemorrhage and edema were less evident than in group 2.

Five days after trauma, the specimens obtained from 


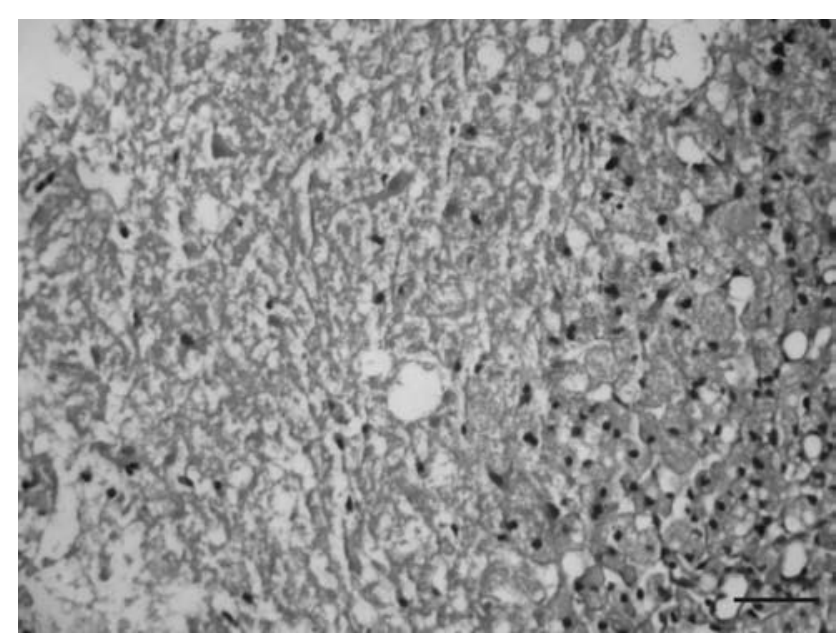

Figure 1. Group 2. A photomicrograph of spinal cord tissue obtained from injured rats 5 days after trauma shows severe vacuolar cystic defects, necrosis, and an extensive infiltration of polymorphonuclear leukocytes and macrophages (hematoxylin and eosin stain, original magnification $\times 20$ )

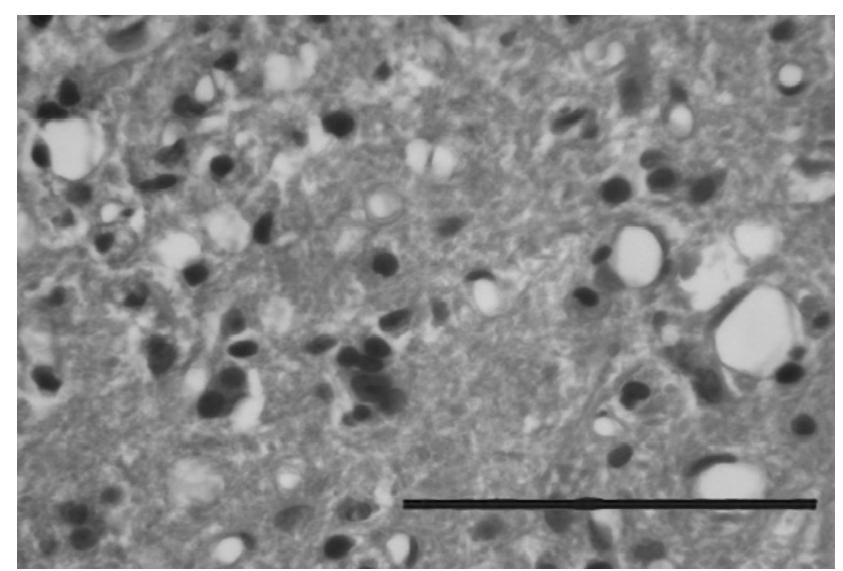

Figure 2. Group 3. A photomicrograph of spinal cord specimens taken from the Q-VD-OPh-treated rats 5 days after SCI shows some vacuolar degeneration and reveals less necrosis than that in group 2 specimens at 5 days. Note that the macrophages and polymorphonuclear cells have not extensively infiltrated hemorrhagic areas (hematoxylin and eosin stain, original magnification $\times 40$ ).

group 2 rats revealed minimal hemorrhage and edema, and sites of apparent previous hemorrhage were cavitated. Neuronal loss and demyelinization of nerve fibers were prominent (Figure 1). Degenerative changes and axonal damage in the spinal cord tissue extended from the epicenter of the lesion in both rostral and caudal directions. Specimens obtained from group 3 rats showed a nearly normal cellular structure of the spinal cord. Cystic vacuolar degeneration was present but less prominent than that in group 2 rats at that time (Figure 2). There were no large vacuoles or clearing areas. In group 3 , the demyelinization
2009; 20: 533-540
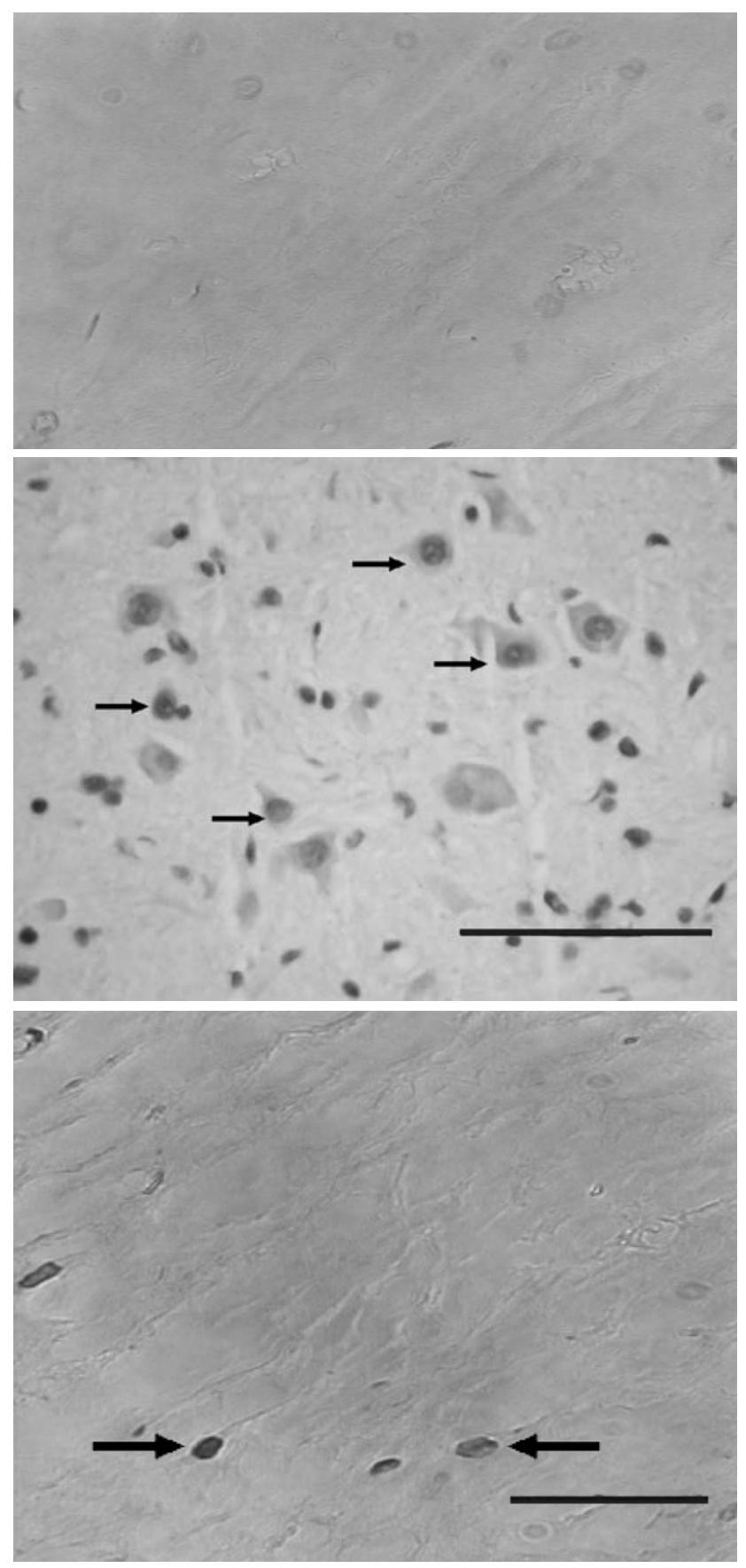

Figure 3. A-C. Spinal cord samples stained with TUNEL 24 hours after injury. A) A photograph from a sham-operated control rat shows no apoptotic cells in the spinal cord tissue (TUNEL, original magnification $\times 40)$. B) White matter taken from group 2 rats reveals numerous TUNELpositive cells (arrows) in the injured zone (TUNEL, original magnification $\times 40$ ). C) A photomicrograph of a spinal cord specimen from group 3 rats shows a few TUNEL-positive cells, which decreased in number after treatment with Q-VD-OPh (TUNEL, original magnification $\times 100)$. 


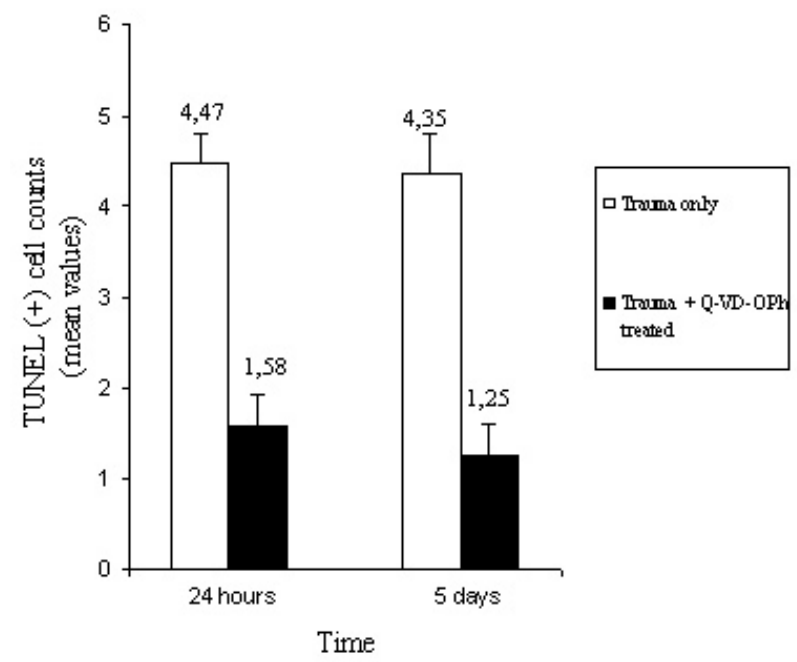

Figure 4. A graph showing the mean apoptotic cell count for each group 24 hours and 5 days after SCI. After injury, the apoptotic cell number in the spinal cord of group 2 rats increased at both time points. Treatment with Q-VD-OPh significantly reduced the apoptotic cell number. There was a statistically significant difference between the mean number of apoptotic cells in the trauma-only rats and that in the $Q-V D-O P h-$ treated rats $(P<.05)$. The bars indicate the standard deviations.

of axons and the loss of neurons were also less extensive than in group 2.

\section{Results of TUNEL staining}

No apoptotic cells were noted in the specimens taken from the sham-operated rats (Figure 3A). In the specimens obtained from the trauma-created rats 24 hours after injury, apoptotic cells were seen in both the gray and the white matter and were especially evident in the posterior graymatter region (Figure 3B). Most of the TUNEL-positive cells were peripheral to the epicenter of the lesion. Some cells were noted in regions both cranial and caudal to the epicenter. The apoptotic cell number ranged from 4.13 to 5 (mean, $4.47 \pm 0.35$ ) (Figure 4). Five days after injury, the apoptotic cell count (mean, $4.35 \pm 0.47$ ) was lower than that noted 24 hours after injury (Figure 4).

In the specimens obtained from the Q-VD-OPh-treated rats (group 3) 24 hours after injury, TUNEL-positive cells were also noted in the slides of the entire spinal cord (Figure $3 \mathrm{C})$, but there were significantly fewer of those cells than there were in the trauma-created controls (group 2 rats) $(\mathrm{P}<.05)$. The mean apoptotic cell count in this group was $1.58 \pm 0.33$ (Figure 4). Five days after injury, Q-VD-OPh treatment had caused a significant decrease in the TUNELpositive cell count (mean, $1.25 \pm 0.34$ TUNEL-positive cells) (Figure 4).
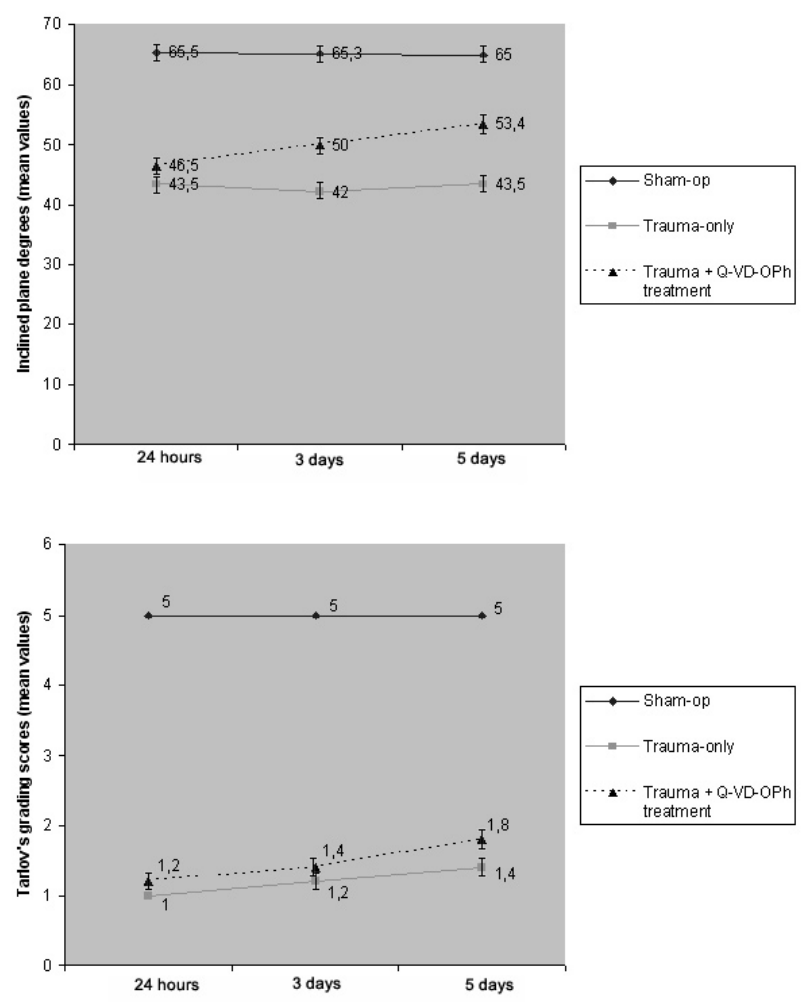

Figure 5. Graphs showing the results of functional assessment experiments in the 3 groups 24 hours, 3 days and 5 days after injury (the values shown are the mean $\pm S D$ of 5 rats for each group). The rats that had been subjected to a trauma of $40 \mathrm{~g}$-cm exhibited significant deficits in hind-limb movement. In contrast, Q-VDOPh-treated rats showed better neurologic postinjury performance than did those in group 2. The inclined plane degrees and modified Tarlov's grading scale scores are shown in graphics $A$ and $B$, respectively. The results of statistical tests confirmed significant differences 24 hours, 3 days, and 5 days after injury between groups 2 and $3(P<.05)$.

\section{Functional recovery experiments}

Twenty-four hours after trauma, the inclined plane degree was as follows: $65.5 \pm 1.97$ in group 1, $43.5 \pm 2.23$ in group 2, and $46.5 \pm 2.10$ in group 3 (Figure 5A). The inclined plane degree was $43.5 \pm 2.23$ on day 5 in the traumatized rats (group 2) but was $53.40 \pm 2.50$ in the treated rats (group 3) (Figure 5A). The mean inclined plane results for the 3 groups are shown in Figure 5.

The mean values according to Tarlov's grading scale 5 days after injury were $5.0 \pm 0.0$ in group $1,1.4 \pm 0.28$ in group 2, and $1.8 \pm 0.34$ in group 3 (Figure $5 \mathrm{~B}$ ). The difference between group 2 and group 3 rats at each time point ( 24 hours, 3 days, and 5 days after trauma) was statistically significant $(\mathrm{P}<.05)$. 


\section{Discussion}

To our knowledge, this study reveals for the first time that using Q-VD-OPh to treat rats subjected to SCI reduces apoptotic cell death, provides significantly superior neuroprotection, and enables the recovery of neurologic function by inhibiting pan-caspases that have been implicated in the secondary damage that occurs after SCI. In this study, $\mathrm{Q}-\mathrm{VD}-\mathrm{OPh}$, a new generation of broad-spectrum caspase inhibitor, was used to inhibit apoptotic cell death after SCI. The possible mechanism of neuroprotection by Q-VD-OPh might involve its strong anticaspase properties.

In prior experimental and clinical studies, researchers have shown that activation of the caspase family is important in the initiation and execution of apoptotic events $\mathrm{s}^{2,3,7,1}$ $0,15,17,19,20,24,29,36$. The process of apoptosis in the cell involves multiple enzymes and molecules at several molecular levels. Therefore, apoptosis may be controlled with various antiapoptotic-based strategies, depending on the target level of apoptosis. Researchers have focused on strategies that target caspases and on most of the key players at the molecular level for the regulation cellular apoptosis and the inhibition of $\mathrm{SCI}^{2}, 6,9,14,16,17,22,28,35$. Q-VD-OPh provides an irreversible thioether bond between aspartic acid (which is derivative in inhibition) and the active cysteine site of the caspase with the 2,6 diflurophenoxy-leaving group. Q-VD$\mathrm{OPh}$ has 3 advantages over other anticaspase inhibitors: it is more effective in preventing apoptosis than are the other inhibitors, it is effective in preventing apoptosis mediated by the 3 major apoptotic pathways, and it is nontoxic to cells, even at a high concentration ${ }^{5}$. The basic properties of Q-VD-OPh cited above make this molecule suitable for the prevention and treatment of apoptosis due to caspase activation. In this experimental study, Q-VD-OPh was administered immediately after SCI, when upstream and downstream cascades of caspases were activated. That exact point in time is important because all caspases are targeted just before their activation.

In a study by Nonner and colleagues ${ }^{23}$, Q-VD-OPh increased the survival of cholinergic neurons that were subjected to experimentally induced stress in cultures from an embryonic rat septum. In a cell culture of rat striatal neurons, White and colleagues ${ }^{36}$ showed that Q-VD-OPh delayed neuronal death after heat-induced stress and produced the greatest increase in cell survival. Patil and Sharma ${ }^{25}$ injected Q-VD-OPh intravitally after ischemia and investigated the subsequent apoptotic death of retinal ganglion cells. They showed that the survival of retinal ganglion cells resulted from the inhibition of ischemia-induced apoptosis. In a study in mice, Vera and colleagues ${ }^{34}$ investigated the therapeutic efficacy of Q-VD-OPh in preventing heat-induced apoptosis. They found that Q-VD-OPh prevented heat-induced germ-cell apoptosis to a significant degree and concluded that the structural design of this agent renders it permeable through the blood-testis barrier. The poor penetrability of several caspases, such as z-VADfmk, into the brain limits their use in clinical practice. $\mathrm{The} \mathrm{OPh}$ group in $\mathrm{Q}-\mathrm{VD}-\mathrm{OPh}$ is primarily responsible for nontoxicity, increased potency, and increased membrane permeability and ensures permeability through the bloodbrain barrier ${ }^{5}$. Yang and colleagues ${ }^{37}$ investigated therapeutic efficacy of Q-VD-OPh in an experimental model of Parkinson's disease and Huntington's disease. They showed that Q-VD-OPh significantly decreased dopamine depletion in the striatum and prevented neuronal loss in the substantia nigra by inhibiting caspases. They concluded that Q-VD-OPh may be useful in the treatment of neurodegenerative diseases. Renolleau and colleagues ${ }^{26}$ tested the effects of Q-VD-OPh in a rat neonatal stroke model. They showed that the administration of Q-VD-OPh reduced cell death and provided significant neuroprotection. In a study performed on mice, Zhu and colleagues ${ }^{40}$ demonstrated that Q-VD-OPh decreased neuronal loss induced by cerebral hypoxia-ischemia and also limited infarct size. In this study in a murine model, treatment with Q-VD-OPh inhibited apoptosis, which in turn limited secondary damage after SCI and improved the recovery of hind-limb function (Figures 2-5). We concluded that the improved recovery after SCI in the Q-VD-OPh-treated rats might be a result of the effects of Q-VD-OPh on antiapoptotic proteins as well as caspases.

\section{Conclusion}

This study showed that treatment with Q-VD-OPh significantly reduced the alteration of spinal cord tissues after SCI and improved the functional recovery of the subjects by inhibiting all caspases involved. A better understanding of the apoptotic mechanisms of this pan-caspase inhibitor might lead to its use in the prevention and treatment of the damage caused by SCI.

\section{Acknowledgments}

We thank Dr. Miktat Kaya, Dr. Şeref Barut and Dr. Bilal Kelten for their technical assistance and help.

\section{References}

1. Allen, A.R.: Remarks on the histopathological changes in the spinal cord due to impact. An experimental study. J Nerv Ment Dis 1914; 41: 141-147.

2. Barut, S., Unlu, Y.A., Karaoglan, A., et al.: The neuroprotective effects of z-DEVD.fmk, a caspase-3 inhibitor, on traumatic spinal cord injury in rats. Surg Neurol 2005; 64: 213-220. 
3. Bresnahan, J.C., Shuman, S.L., Beattie, M.S.: Evidence for apoptosis of oligodendroglia in long tracts undergoing wallerian degeneration after spinal cord injury (SCI) in monkeys. Soc Abstr Neurosci 1996; 22: 1185.

4. Casha, S., Yu, W.R., Fehlings, M.G.: Oligodendroglial apoptosis occurs along degenerating axons and is associated with FAS and p75 expression following spinal cord injury in the rat. Neuroscience 2001; 103: 203-218.

5. Caserta, T.M., Smith, A.N., Gultice, A.D., et al.: Q-VD$\mathrm{OPh}$, a broad spectrum caspase inhibitor with potent antiapoptotic properties. Apoptosis 2003; 8: 345-352.

6. Colak, A., Karaoglan, A., Barut, S., et al.: Neuroprotection and functional recovery after application of the caspase- 9 inhibitor z-LEHD-fmk in a rat model of traumatic spinal cord injury. J Neurosurg Spine 2005; 2: 327-334.

7. Crowe, M.J., Bresnahan, J.C., Shuman, S.L., et al.: Apoptosis and delayed degeneration after spinal cord injury in rats and monkeys. Nat Med 1997; 3: 73-76.

8. Deveraux, Q.L., Stennicke, H.R., Salvesen, G.S., Reed, J.C.: Endogenous inhibitors of caspases. J Clin Immunol. 1999; 19: 388-398.

9. Ekert, P.G., Silke, J., Vaux, D.L.: Caspase inhibitors. Cell Death Differ 1999; 6: 1081-1086.

10. Emery, E., Aldana, P., Bunge, M.B., et al.: Apoptosis after traumatic human spinal cord injury. J Neurosurg 1998; 89: 911-920.

11. Gavrieli, Y., Sherman, Y., Ben-Sasson, S.A.: Identification of programmed cell death in situ via specific labeling of nuclear DNA fragmentation. J Cell Biol 1992; 119: 493-501.

12. Ghanem, M.M., Battelli, L.A., Mercer, R.R., et al.: Apoptosis and Bax expression are increased by coal dust in the polycyclic aromatic hydrocarbon-exposed lung. Environ Health Perspect 2006; 114: 1367-1373.

13. Kato, H., Kanellopoulos, G.K., Matsuo, S., et al.: Neuronal apoptosis and necrosis following spinal cord ischemia in the rat. Exp Neurol 1997; 148: 464-474.

14. Keane, R.W., Kraydieh, S., Lotocki, G., et al: Apoptotic and anti-apoptotic mechanisms following spinal cord injury. J Neuropathol Exp Neurol 2001; 60: 422-429.

15. Kerr, J.F., Wyllie, A.H., Currie, A.R.: Apoptosis: a basic biological phenomenon with wide-ranging implications in tissue kinetics. Br J Cancer 1972; 26: 239-257.

16. Li, H., Colbourne, F., Sun, P., et al.: Caspase inhibitors reduce neuronal injury after focal but not global cerebral ischemia in rats. Stroke 2000; 31: 176-182.

17. Li, M., Ona, V.O., Chen, M., et al.: Functional role and therapeutic implications of neuronal caspase- 1 and -3 in a mouse model of traumatic spinal cord injury. Neuroscience 2000; 99: 333-342.

18. Liu, X.Z., Xu, X.M., Hu, R., et al.: Neuronal and glial apoptosis after traumatic spinal cord injury. J Neurosci 1997; 17: 5395-5406.

19. Lou, J., Lenke, L.G., Ludwig, F.J., O'Brien, M.F.:
Apoptosis as a mechanism of neuronal cell death following acute experimental spinal cord injury. Spinal Cord 1998; 36: 683-690.

20. Lu, J., Ashwell, K.W., Waite, P.: Advances in secondary spinal cord injury: role of apoptosis. Spine 2000; 25: 1859-1866.

21. Martin, U., Jarasch, N., Nestler, M., et al.: Antiviral effects of pan-caspase inhibitors on the replication of coxsackievirus B3. Apoptosis 2007; 12: 525-533.

22. Nicholson, D.W.: From bench to clinic with apoptosisbased therapeutic agents. Nature 2000; 407: 810-816.

23. Nonner, D., Panickar, K., Barrett, E.F., Barrett, J.N.: Bone morphogenetic proteins and neurotrophins provide complementary protection of septal cholinergic function during phosphatase inhibitor-induced stress. J Neurochem 2004; 91: 77-87.

24. Raff, M.: Cell suicide for beginners. Nature 1998; 396: 119-122.

25. Patil, K., Sharma, S.C.: Broad spectrum caspase inhibitor rescues retinal ganglion cells after ischemia. Neuroreport 2004; 15: 981-984.

26. Renolleau, S., Fau, S., Goyenvalle, C., et al.: Specific caspase inhibitor Q-VD-OPh prevents neonatal stroke in P7 rat: a role for gender. J Neurochem 2007; 100: 1062-1071.

27. Rivlin, A.S., Tator, C.H.: Objective clinical assessment of motor function after experimental spinal cord injury in the rat. J Neurosurg 1977; 47: 577-581.

28. Rudel, T.: Caspase inhibitors in prevention of apoptosis. Herz 1999; 24: 236-241.

29. Samali, A., Zhivotovsky, B., Jones, D., et al.: Apoptosis: cell death defined by caspase activation. Cell Death Differ 1999; 6: 495-496.

30. Springer, J.E., Azbill, R.D., Knapp, P.E.: Activation of the caspase-3 apoptotic cascade in traumatic spinal cord injury. Nat Med 1999; 5: 943-946.

31. Tarlov, I.M.: Spinal Cord Compression: Mechanism of Paralysis and Treatment. Springfield, Ill: Charles C Thomas; 1957

32. Tewari, M., Quan, L.T., O'Rourke, K., et al.: Yama/ CPP32 beta, a mammalian homolog of CED-3, is a CrmAinhibitable protease that cleaves the death substrate poly(ADPribose) polymerase. Cell 1995; 81: 801-809.

33. Thompson, C.B.: Apoptosis in the pathogenesis and treatment of disease. Science 1995; 267: 1456-1462.

34. Vera, Y., Rodriguez, S., Castanares, M., et al.: Functional role of caspases in heat-induced testicular germ cell apoptosis. Biol Reprod 2005; 72: 516-522.

35. Villa, P., Kaufmann, S.H., Earnshaw, W.C.: Caspases and caspase inhibitors. Trends Biochem Sci 1997; 22: 388-393.

36. White, M.G., Emery, M., Nonner, D., Barrett, J.N.: Caspase activation contributes to delayed death of heat-stressed striatal neurons. J Neurochem 2003; 87: 958-968.

37. Yang, L., Sugama, S., Mischak, R.P., et al.: A novel systemically active caspase inhibitor attenuates the toxicities of MPTP, malonate, and 3NP in vivo. Neurobiol Dis 2004; 17: 250-259.

38. Yong, C., Arnold, P.M., Zoubine, M.N., et al.: 
Apoptosis in cellular compartments of rat spinal cord after severe contusion injury. J Neurotrauma 1998; 15: 459-472.

39. Zheng, X., Chou, P.M., Mirkin, B.L., Rebbaa, A.: Senescence-initiated reversal of drug resistance: specific role of cathepsin L. Cancer Res 2004; 64: 1773-1780.

40. Zhu, C., Wang, X., Huang, Z., et al.: Apoptosis-inducing factor is a major contributor to neuronal loss induced by neonatal cerebral hypoxia-ischemia. Cell Death Differ 2007; 14: $775-84$.

\section{Comment to the article $Q-V D-O P h$, a pancaspase inhibi- tor, reduces trauma-induced apoptosis and improves the recovery of hind-limb function in rats after spinal cord injury by Çolak et al.}

The authors studied the antiapoptotic effect of a new pan-caspase-inhibitor (Q-VD-Oph) in a rat model of spinal cord injury (SCI) showing that this treatment reduces the number of apoptotic cells (TUNEL-positive) in the injured spinal cord tissue. Moreover, this therapy is associated to better neurological function scores, when compared with controls. The study is interesting, since there is not experience with the use of Q-VD-Oph in traumatic lesions of the Central Nervous System, and it outlines a potential clinical utility. At least theoretically, Q-VD-Oph offers the advantage that its antiapoptotic effect is more significant than other antiapoptotic substances, just as ZVAD-fmk and BOC-D-fmk, and it blocks caspase 9/3, caspase 8/10 and caspase 12. Furthermore Q-VD-Oph also seems to have very low toxicity, even when it is used to high concentrations.

It is obvious that the study of apoptosis after spinal cord or brain trauma offers an interesting field of research, and we must thank the authors for providing a new work that should be added to their previous publications on the antiapoptotic therapy after $\mathrm{SCI}^{1-6}$.

Nevertheless, when studies on apoptosis are carried out, some considerations should be made. Although apoptosis is a constant finding after SCI, at present it is difficult to obtain a clear relationship among apoptosis and neurological sequels, therefore, it is difficult to valuate the clinical utility of antiapoptotic therapies. On the other hand, in these studies high variability exists in the immunohistochemical data, according to the techniques used, and it is well-known that TUNEL-technique can also immunostain necrotic cells ${ }^{7-9}$. Furthermore, keeping in mind the presence of inflammatory cells in the initial phases after SCI, and the different functional significance of the neurons and glial cells, seems convenient to know with certainty, by means of double immunostain, the cytological characterization of apoptotic cells.
Çolak, A.; Antar, V.; Karaoğlan, A.; Akdemir, O.; Sahan, E.; Çelik, Ö.; Sağmanligil, A.: Q-VD-OPh, a pancaspase inhibitor, reduces trauma-induced apoptosis and improves the recovery of hind-limb function in rats after spinal cord injury. Neurocirugía 2009; 20: 533-540.

Address correspondence to: Ahmet Colak, MD. Kartaltepe Mahallesi, Terakki Caddesi 47/7. Bakirkoy, Istanbul, Turkey.

E-mail: drahmetcolak@yahoo.com

\section{References}

1. Akdemir, O., Berksoy, I., Karaoğlan, A., et al.: Therapeutic efficacy of Ac-DMQD-CHO, a caspase 3 inhibitor, for rat spinal cord injury. J Clin Neurosci 2008; 15: 672-678.

2. Akdemir, O., Uçankale, M., Karaoğlan, A., et al.: Therapeutic efficacy of SJA6017, a calpain inhibitor, in rat spinal cord injury. J Clin Neurosci 2008; 15: 1130-1136.

3. Barut, S., Unlü, Y.A., Karaoğlan, A., et al.: The neuroprotective effects of z-DEVD.fmk, a caspase-3 inhibitor, on traumatic spinal cord injury in rats. Surg Neurol 2005; 64: 213-220.

4. Colak, A., Karaoğlan, A., Barut, S., Köktürk, S., Akyildiz, A.I., Taşyürekli, M.: Neuroprotection and functional recovery after application of the caspase-9 inhibitor z-LEHD-fmk in a rat model of traumatic spinal cord injury. J Neurosurg Spine 2005; 2: 327-334.

5. Colak, A., Kelten, B., Sağmanligil, A., et al.: Tauroursodeoxycholic acid and secondary damage after spinal cord injury in rats. J Clin Neurosci 2008; 15: 665-671.

6. Karaoğlan, A., Kaya, E., Akdemir, O., et al.: Neuroprotective effects of Ac.YVAD.cmk on experimental spinal cord injury in rats. Surg Neurol 2008; 69: 561-567.

7. Vaquero, J., Zurita, M., Oya, S., Aguayo, C., Bonilla C.: Early administration of methylprednisolone decreases apoptotic cell death after spinal cord injury. Histol Histopathol 2006; 21: 1091-1102.

8. Zurita, M., Vaquero, J., Oya, S., Morales C.: Effects of dexamethasone on apoptosis-related cell death after spinal cord injury J Neurosurg (Spine 1) 2002; 96: 83-89.

9. Zurita, M., Vaquero, J., Zurita, I.: Presence and significance of CD-95 (FAS/APO1) expression after spinal cord injury. J Neurosurg (Spine 2). 2001; 94: 257-264.

J. Vaquero Madrid 